\title{
ANALISIS MINAT BACA SISWA KELAS V SEKOLAH DASAR DALAM PEMBELAJARAN DARING
}

\author{
Ema Dian Afriani $^{1}$, Siti Masfuah ${ }^{2}$, Mila Roysa ${ }^{3}$ \\ PGSD Universitas Muria Kudus \\ Email: emadian044@gmail.com
}

Info Artikel

Sejarah Artikel:

Diserahkan: 28-08-2021

Direvisi: 03-11-2021

Disetujui: 24-11-2021

Keywords:

Minat baca siswa, Pembelajaran Daring.

\section{Abstract}

This study aims to 1) analyze the factors causing the high reading interest of children in Tendas Village and 2) analyze efforts to maintain children's reading interest in Tendas Village during the pandemic. This study uses a qualitative approach. The form in this study does not prioritize numbers but prioritizes the appreciation of the interactions between concepts or those that are being studied empirically. The researcher took the research subjects of fifth grade students and fifth grade students' parents. This research used the technique of collecting observations, interviews, documentation and recording. The results showed that the initial condition of students' reading interest in online learning currently tends to be high and there are some students who are still enthusiastic about reading books at home. Factors that influence students' reading interest are the environment, the availability of reading books and the encouragement from the family environment. While several efforts were made to maintain children's interest in reading during the pandemic, including adding facilities and infrastructure in the form of more varied reading books, collaboration between the school and parents to provide opportunities for students to read the books they like, and building a network of good playmates. have a good reading interest

\begin{abstract}
Abstrak
Penelitian ini bertujuan untuk 1) menganalisis faktor penyebab tingginya minat baca anak di Desa Tendas dan 2) menganalisis upaya mempertahankan minat baca anak di Desa Tendas selama masa pandemi. Penelitian ini menggunakan pendekatan kualitatif. Bentuk pada penelitian ini tidak mengutamakan pada angka tetapi mengutamakan kedalam penghayatan terhadap interaksi antar konsep atau yang sedang dikaji secara empiris. Peneliti mengambil subjek penelitian siswa kelas V dan orang tua siswa kelas V. Penelitian ini menggunakan teknik pengumpulan observasi, wawancara, dokmentasi dan pencatatan. Hasil penelitian menunjukkan bahwa kondisi awal minat baca siswa dalam pembelajaran daring saat ini cenderung tinggi dan ada ada beberapa siswa yang masih semangat dalam membaca buku saat di rumah. Faktor yang mempengaruhi minat membaca siswa yaitu ligkungan, tersedianya sarana buku bacaan serta adanya dorongan dari lingkungan keluarga. Sementara beberapa upaya dilakukan untuk mempertahankan minat baca anak selama masa pandemic diantaranya melalui, penambahan sarana dan prasarana berupa buku bacaan yang lebih bervariasi, kerjasama antara pihak sekolah dan orang tua untuk memberikan kesempatan pada siswa untuk membaca buku yang disukainya, dan membangun jaringan teman bermain yang memiliki minat baca yang baik.
\end{abstract}




\section{PENDAHULUAN}

Pendidikan memiliki peran yang sangat penting dalam mewujudkan impian dan mencerdaskan kehidupan bangsa. Pada era globalisasi ini semua masalah dan informasi dapat dengan cepat diketahui oleh seluruh dunia melalui berbagai media yang ada, termasuk informasi tentang perkembangan ilmu pengetahuan dan teknologi. Salah satu kegiatan yang digunakan sebagai penyebaran informasi dalam belajar yaitu membaca menjadi salah satu kegiatan yang sangat penting. Kemajuan teknologi saat ini sudah terlihat berkembang pesat seperti, HP dan alat teknologi yang lainnya. Pratama, dkk (2018:59) menyebutkan bahwa minat sebagai rasa lebih suka dan rasa ketertarikan pada suatu hal atau aktivitas, tanpa ada yang menyuruh. Siswa yang mempunyai minat seperti membaca yang tinggi akan selalu senang membaca buku-buku bacaan dan mempelajari isi yang tersampaikan di dalam buku tersebut.

Solikhah (2016:13) mengemukakan bahwa membaca adalah proses yang dilakukan serta dipergunakan oleh pembaca untuk memperoleh pesan yang hendak disampaikan oleh penulis melalui media kata-kata atau bahasa tulis. Mengingat pentingnya membaca dalam kehidupan sehari-hari khususnya bagi siswa, maka minat baca bagi anak wajib dipupuk sejak sedini mungkin. Kebiasaan membaca yang baik berdampak positif terhadap hasil belajar siswa (Putra, 2021). Karena membaca akan membuka jendela cakrawala yang bisa membuat siswa lebih tanggap dan bertambahnya wawasan ilmu pengetahuan. Adanya pandemi saat ini, siswa diharuskan belajar dan mengikuti pembelajaran dari rumah untuk memenuhi pendidikan sekolah. Dalam belajar siswa pasti mempunyai minat atau kesukaan dalam pembelajaran. Minat siswa dalam pelajaran akan menambah semangat siswa dalam mengikuti pembelajaran dari rumah.

Ratnasari (2011:16) mengemukakan bahwa minat baca adalah suatu perhatian yang kuat dan mendalam disertai dengan perasaan senang terhadap kegiatan membaca sehingga dapat mengarahkan seseorang untuk membaca dengan kemauannya sendiri atau dorongan dari luar. Minat membaca juga merupakan perasaan senang seseorang terhadap bacaan karena adanya pemikiran bahwa dengan membaca itu dapat diperoleh kemanfaatan bagi dirinya. Adanya faktor-faktor yang mempengaruhi minat baca siswa menurut Soeatminah, dkk. (dalam Maulidia, 2018:42-44) yakni bakat, jenis kelamin, tingkat pendidikan, kebiasaan, bahan bacaan, dan lingkungan sekolah. Berdasarkan beberapa faktor tersebut dapat dirumuskan indikator-indikator mengenai minat baca. Indikator-indikator adanya minat membaca pada seseorang menurut Sudarsana dan Bastiano (2010: 427) ada empat aspek yang dapat digunakan untuk mengetahui tingkat minat baca seseorang, yaitu 1) Kesenangan membaca, 2) Kesadaran akan manfaat membaca, 3) Frekuensi membaca dan 4) Kuantitas bacaan.

Minat membaca siswa harus di terapkan walaupun dalam keadaan pandemi saat ini yang mengharuskan siswa belajar dan mengikuti pembelajaran dari rumah. Siswa harus meluangkan waktu untuk membaca buku walau di rumah banyak digunakan dengan bermain, menonton TV, atau bermain game.

$$
\text { Pembelajaran diganti dengan }
$$

pembelajaran dalam jaringan (daring), atau sering disebut online. Adanya masalah saat ini program sekolah berbeda, karena pandemi sekolah-sekolah diliburkan dan siswa dituntut untuk belajar di rumah dan mengikuti pembelajaran melalui daring. Pembelajaran daring dilaksanakan untuk mencegah penyebaran virus dalam pandemi saat ini. Pembelajaran daring dapat dipahami suatu pendidikan yang diselenggarakan oleh sekolah dasar yang jenis belajar mengajarnya tidak langsung, yaitu guru berada di lokasi terpisah dengan siswa untuk menyalurkan bahan ajar sehingga memerlukan sistem telekomunikasi interaktif untuk menghubungkan keduanya. Komunikasi dua arah pada program pembelajaran daring antara guru dengan siswa atau antara siswa dengan siswa, dan guru dengan guru akan semakin baik karena banyaknya pilihan media komunikasi yang tersedia (Sobron, 2019:1).

Untuk mengetahui penyebab minat baca siswa dan cara mempertahankan minat baca 
Ema Dian Afriani, SIti Masfuah, dan Mila Roysa

Analisis Minat Baca Siswa Kelas V Sekolah Dasar dalam Pembelajaran Daring

Jurnal Prasasti Ilmu. Volume 1 Nomor 3 hlm. 21-27

siswa, peneliti melakukan observasi dan wawancara kepada siswa kelas V sekolah dasar dan orang tua siswa di Desa Tendas berkaitan dengan pelaksanaan pembelajaran daring yang dilaksankan pada tanggal 12 Juli 2021 menunjukkan bahwa masih ada beberapa siswa yang senang dan semangat untuk membaca buku dalam pembelajaran daring saat ini. Hasil wawancara minat baca siswa kelas V sekolah dasar yang tinggi dalam pembelajaran daring di Desa Tendas menunjukkan bahwa selama ada waktu luang atau setelah mengikuti pembelajaran daring siswa selalu menyempatkan membaca buku-buku bacaan di rumah. Siswa senang dan semangat dalam membaca buku dan dapat memanfaatkan waktunya selama pandemi ini dengan membaca buku daripada bermain HP atau bermain game. Masih banyak juga siswa yang tidak suka membaca dan lebih mementingkan bermain HP atau menonton TV. Siswa yang minat bacanya tinggi pasti tahu manfaat dalam membaca buku untuk dirinya kelak di masa depan. Banyak manfaat dari membaca buku dan mendapat ilmu pendidikan dan pesan moral yang terdapat dalam isi buku bacaan. Minat baca pada siswa kelas V SD di Desa Tendas yang tinggi mempunyai beberapa faktor penyebab minat baca siswa kelas $\mathrm{V}$ yang tinggi dalam pembelajaran daring saat ini yaitu pengaruh dari faktor-faktor ligkungan, tersedianya sarana buku bacaan serta adanya dorongan dari lingkungan keluarga seperti orang tua. Orang tua berperan penting dalam mengembangkan minat baca siswa saat di rumah, agar dapat membantu memberi dorongan semangat dan membimbing siswa dalam pembelajaran daring saat ini. Peneliti juga melakukan wawancara terhadap orang tua siswa bahwa orang tua siswa harus ikut membimbing anaknya dalam pembelajaran daring saat ini dan mempertahankan minat baca siswa selama di rumah. Orang tua siswa selalu menyediakan waktu luang untuk anaknya membaca buku dan menyediakan buku-buku bacaan agar anaknya memperoleh ilmu pendidikan dan wawasan luas dari manfaat membaca buku.

Hal ini juga sesuai dengan hasil penelitian yang dilakukan oleh Tarigan (2018) berdasarkan penelitian yang telah dilaksanakan, maka dapat disimpulkan produk buku cerita bergambar yang dikembangkan dalam penilitian ini dinyatakan "efektif" digunakan dalam meningkatkan minat baca dan membaca pemahaman siswa kelas IV SD. Produk buku cerita dikembangkan pada subtema mencintai lingkungan. Hal ini terbukti dari hasil nilai uji efektivitas pada minat baca 26,317 dengan probabilitas (sig.) 0,000. Berdasarkan hasil penelitian yang dilakukan oleh Mursalim, Solehun dan Pramudia (2020) bahwa penelitian ini menunjukan bahwa motivasi orang tua berperan penting dalam membangun minat baca siswa karena dorongan yang diberikan orang tua mampu memngembangkan minat membaca pada siswa. Hal itu dibuktikan dari hasi penelitian yaitu $5 \%$ siswa sudah mendapatkan motivasi sangat baik dan sekitar 80\% siswa SD Inpres 26 Kabupaten Sorong sudah mendapakan motivasi yang baik dari orang tua sehingga memacu semangat untuk terus membaca. Dari total sempel yang diambil dapat dilihat bahwa jumlah skor motivasi orang tua 71,5. Angka tersebut menunjukan kualitas motivasi orang tua cukup tinggi atau baik, sedangkan untuk minat baca memperoleh total skor 74,4 dengan kategori tinggi atau baik. Dapat dilihat bahwa motivasi orang tua mempunyai pengaruh terhadap minat baca siswa kelas III SD Inpres 26 Kabupaten Sorong. Hal tersebut bisa meningkat apabila orang tua mampu memberikan motivasi secara baik dan terus menerus kepada siswa.

Berdasarkan hasil para ahli dapat disimpulkan bahwa buku-buku bacaan yang digemari siswa dapat membantu minat baca siswa yang tinggi dengan efektif dan mampu memberi pemahaman siswa tentang ilmu pendidikan dan pesan moral yang terkandung dalam buku bacaan. Dororngan yang diberikan orang tua juga penting dalam membantu semangat siswa dalam mempertahankan minat baca siswa yang tinggi.

\section{METODE PENELITIAN}

Penelitian ini menggunakan metode penelitian kualitatif. Dalam penelitian yang dilakukan, data yang diperoleh akan disajikan 
secara deskriptif kualitatif yang menerangkan dan menggambarkan mengenai bagaimana faktor penyebab minat baca siswa kelas $\mathrm{V}$ yang tinggi dalam pembelajaran daring di desa Tendas dan Bagaimana cara mempertahankan minat baca siswa kelas V dalam pembelajaran daring di desa Tendas. Kegiatan penelitian dilaksanakan di lingkungan Rt 01 Rw 02 Desa Tendas yang beralamat Jl. Lingkar Tayu-Jepara Kecamatan Tayu Kabupaten Pati. Dimana di dalam penelitian ini akan memperdalam minat baca siswa kelas $\mathrm{V}$ sekolah dasar yang diterapkan dalam pembelajaran daring. Teknik pengumpulan data dilakukan dengan cara observasi, wawancara dan dokumentasi. Moleong (2012:330) menjelaskan bahwa triangulasi adalah teknik pemeriksaan keabsahan data yang memanfaatkan sesuatu yang diluar data untuk keperluan pengecekan atau sebagai pembanding terhadap data itu. Untuk uji keabsahan data menggunakan triangulasi metode. Untuk memperoleh kevalidan data peneleitian, peneliti menggunakan beberapa teknik pengumpulan data. Selain melakukan wawancara kepada informan, peneliti juga melakukan pengamatan kegiatan sehari-hari informan untuk mendapatkan data minat baca anak selama masa pandemi ini. Penggunaan kedua teknik tersebut dimaksudkan sebagai pembanding untuk memperkuat keabsahan data. Setelah data terkumpul dan valid, diolah dengan teknik analisis data dengan mereduksi data, penyajian data dan menarik kesimpulan. Alur proses analisis data dapat dilihat pada gambar bagan di bawah ini.

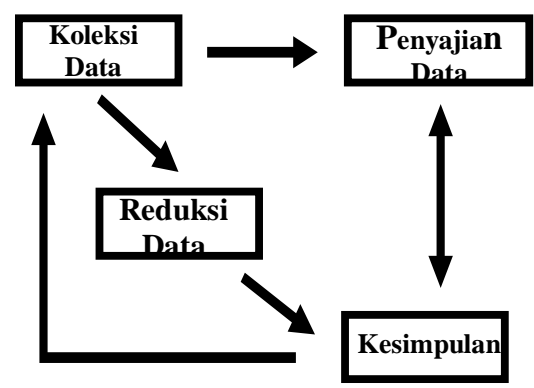

Gambar 1. Bagan Analisis Data

\section{HASIL DAN PEMBAHASAN}

Masa pandemi berdampak pada berbagai aspek, salah satunya adalah dunia pendidikan. Proses pembelajaran menjadi terganggu dengan adanya pandemi ini. Guru dan siswa harus menyesuaikan diri untuk bisa tetap melaksanakan pembelajaran selama masa pandemi ini. Pembelajaran daring menjadi solusi agar proses belajar mengajar tetap berlangsung.

Anak-anak usia sekolah dasar di Desa Tendas sudah melaksanakan pembelajaran daring hampir dua tahun lamanya. Sekolah ini telah menerapkan gerakan literasi lama sebelum adanya masa pandemi. Kegiatan tersebut biasanya diwujudkan dalam bentuk kegiatan membaca 10 menit sebelum kegiatan belajar mengajar berlangsung. Hal ini sejalan dengan pernyataan kepala sekolah saat wawancara.

"Kegiatan ini (liteasi) sudah berlangsung sejak tahun 2018. Kegiatan kami yang sudah berjalan, sebelum pembelajaran dimulai mereka kami beri waktu untuk membaca 1 buku selama 10 menit."

Selama pandemi berlangsung, kegiatan membaca 10 menit sebelum pembelajaran menjadi terganggu. Sekolah mengalami kesulitan untuk terus membiasakan kegiatan membaca pada siswa. Kondisi ini ternyata berbanding terbalik. Dari 28 siswa di kelas V, ada 19 anak yang masih memiliki kebiasaan membaca yang baik. Ada berbagai macam faktor penyebab tetap terjaganya minat baca anak selama masa pandemi berlangsung.

\section{a. Faktor Penyebab Tingginya Minat Baca Siswa Kelas V dalam Pembelajaran Daring di Desa Tendas}

Hasil wawancara peneliti mengenai faktor penyebab minat baca siswa yang tinggi dalam pembelajaran daring dilakukan kepada siswa kelas $\mathrm{V}$ dan orang tua siswa.

Adanya faktor-faktor yang mempengaruhi minat baca siswa menurut Soeatminah, dkk. (dalam Maulidia, 2018:42-44) yakni bakat, jenis kelamin, tingkat pendidikan, kebiasaan, bahan bacaan, dan lingkungan sekolah. 
"Suka sekali membaca, karena banyak buku-buku yang bagus dan terdapat banyak pesan moral dalam setiap isi buku cerita. Saya juga sering membaca setelah mengikuti pembelajaran daring."

Berdasarkan hasil wawancara dengan siswa FAZ dapat disimpulkan bahwa terdapat faktor-faktor penyebab minat baca pada kelas $\mathrm{V}$ yang tinggi dalam pembelajaran daring di Desa Tendas yaitu siswa gemar dalam membaca dan merasa senang dalam membaca buku cerita. Faktor yang terdapat dalam penyebab minat baca siswa FAZ yang tinggi dalam pembelajaran daring yakni jenis kelamin, tingkat pendidikan yang tinggi karena siswa FAZ memiliki prestasi yang baik dan cenderung selalu membaca buku bacaan, kebiasaan yang selalu membaca buku setelah mengikuti pembelajaran daring dan bahan bacaan yang di sukai oleh siswa FAZ adalah buku cerita yang memiliki banyak gambar. Siswa FAZ juga mendapat dorongan dari orang tua dalam memotivasi dirinya untuk membaca buku dan kegiatan belajarnya. Nurjanah \& Hakim (dalam Apriliani dan Radia, 2020: 995) mengemukakan bahwa buku cerita bergambar memiliki fungsi yang dapat digunakan sebagai penghias dan pendukung dalam cerita yang dapat membantu memudahkan proses pemahaman terhadap isi buku tersebut.

Untuk mengetahui lebih lanjut tentang siswa FAZ peneliti melakukan wawancara kepada orangtua siswa $\mathrm{Z}$ yakni Ibu M.

"Saya sering melihat anak saya membaca buku setelah mengikuti pembelajaran daring dan di saat mempunyai waktu luang. Saya selalu memantau dan membimbing anak saya dalam membaca buku dari waktu dia masih kecil."

Berdasarkan hasil wawancara dengan orang tua siswa FAZ yaitu Ibu M menyimpulkan bahwa terdapat faktor faktor penyebab minat baca pada kelas $\mathrm{V}$ yang tinggi dalam pembelajaran daring di Desa Tendas yaitu salah satunya dari orang tua, seperti beliau selalu memberi perhatian untuk anaknya dalam kegiatan yang baik, Ibu M sudah menerapkan kegiatan membaca buku sejak anaknya usia dini agar anak tersebut lancar dalam membaca dan dapat menemukan beberapa ilmu pengetahuan dan juga pesan moral dari setiap buku yang dibaca. Mursalim, dkk. (2020: 112) mengemukakan bahwa motivasi orang tua yang diberikan kepada anak sangatlah penting karena membawa pengaruh yang besar dalam keberhasilan anak tersebut di masa depan. Orang tua tidak hanya memberikan perhatian namun harus memberikan dorongan yang lebih dalam setiap tahap pembelajaran anak.

Selanjutnya peneliti melakukan wawancara dengan siswa TFZ yang berteman dengan siswa FAZ, mereka sering bersama dan mempunyai minat membaca buku yang sama.

"Saya suka membaca buku karena banyak manfaat dari membaca buku. Buku-buku yang sering saya baca yaitu seperti buku cerita, dongeng, dan buku pengetahuan lainnya. Saya sering membaca buku saat ada waktu luang di rumah."

Berdasarkan hasil wawancara dengan siswa TFZ dapat disimpulkan bahwa terdapat faktor faktor penyebab minat baca pada kelas $\mathrm{V}$ yang tinggi dalam pembelajaran daring di Desa Tendas yaitu siswa TFZ gemar membaca buku apa saja maupun fiksi atau non fiksi dalam pembelajaran daring saat ini, karena dari banyak membaca buku siswa TFZ akan mendapatkan banyak ilmu pengetahuan dan wawasan luas untuk bekal dirinya melanjutkan ke jenjang yang tinggi dengan membaca berbagai macam jenis buku. Faktor yang terdapat dalam penyebab minat baca siswa TFZ yang tinggi dalam pembelajaran daring juga sama seperti siswa FAZ yakni jenis kelamin, tingkat pendidikan yang tinggi karena siswa TFZ memiliki prestasi yang baik dan cenderung selalu membaca buku bacaan, kebiasaan yang selalu membaca buku apa saja dan buku-buku bacaan yang dapat memberikan ilmu pengetahuan. Patiung (2016: 370) mengemukakan bahwa untuk mengerti apa yang kita baca, tergantung pada mengapa dan bagaimana kita membaca. Dalam hal ini, jika karena kita mau, karena suka, artinya kita siap dan tahu bagaimana cara membaca dan belajar.

$$
\text { Selanjutnya peneliti melakukan }
$$
wawancara dengan orangtua siswa TFZ yakni Ibu NA. 
"Saya selalu melihat anak saya membaca buku bersama temannya atau saat sedang di rumah. Anak saya menyukai buku apa saja seperti buku cerita, dongeng, sejarah dan buku pengetahuan lainnya. Saya selalu memberi dorongan semangat untuk anak saya dalam melakukan kegiatan belajar dan membaca buku di masa pembelajaran daring saat ini."

Berdasarkan hasil wawancara dengan Ibu NA, peneliti menyimpulkan bahwa terdapat faktor-faktor penyebab minat baca pada kelas $\mathrm{V}$ yang tinggi dalam pembelajaran daring di Desa Tendas yaitu salah satunya dari orang tua yang selalu memberi motivasi atau dorongan untuk anaknya dalam membaca buku, Ibu NA juga memberi perhatian untuk anaknya supaya tidak melakukan kegiatan yang salah selama pembelajaran daring. Ibu NA juga memberikan waktu luang untuk anaknya dalam membaca buku, karena membaca itu penting untuk bekal anaknya kelak dan juga mengetahui manfaatmanfaat dalam membaca buku. Hill dan Tyson (dalam Ama, 2021: 226) menjelaskan bahwa pentingnya orangtua menyiapkan masa depan anak sejak awal saat anak bersekolah, karena hal ini adalah bentuk yang continue sampai anak meraih keberhasilan akademik dalam belajar dan menggapai cita-citanya kedepan.

Peneliti juga melakukan penelitian dengan teman siswa FAZ dan TFZ yang juga mempunyai minat membaca buku yang sama yaitu siswa HA.

"Saya senang membaca buku dongeng karena terdapat banyak gambar yang lucu dan menarik. Banyak pesan moral yang terdapat pada isi bacaan buku dongeng. Sejak pembelajaran daring dilakukan saya sering membaca buku-buku saat mempunyai waktu luang di rumah."

Berdasarkan hasil wawancara dengan siswa HA dapat disimpulkan bahwa terdapat faktor-faktor penyebab minat baca pada kelas V yang tinggi dalam pembelajaran daring di Desa Tendas yaitu siswa HA mempunyai minat membaca buku dongeng yang terdapat gambargambar lucu dan menarik. Faktor yang terdapat dalam penyebab minat baca siswa HA yang tinggi dalam pembelajaran daring yakni jenis kelamin, kebiasaan yang selalu membaca buku setelah mengikuti pembelajaran daring dan bahan bacaan yang di sukai oleh siswa HA adalah buku dongeng yang memiliki banyak gambar dan menarik. Siswa HA selalu membaca buku bersama temannya saat mempunyai waktu luang atau setelah mengerjakan tugas dari guru. Artana (2017: 31) mengemukakan bahwa dongeng adalah media yang paling baik untuk mengajarkan bahasa dan literasi. Dongeng mengandung ungkapan bahasa yang eksploratif dan imajinatif, yang memungkinkan anak-anak berpikir, bercermin diri dan bertanya pada eksistensi dirinya, karena dongeng menyajikan keindahan dan renungan hidup.

Selanjutnya peneliti juga melakukan wawancara dengan orangtua siswa HA yaitu Ibu IS.

"Saya tidak terlalu memantau anak saya saat di rumah karena saya sibuk bekerja. Saya selalu melihat anak saya membaca buku saat malam hari ketika selesai belajar. Kadang saya juga membelikan buku bacaan untuk anak saya karena saya tahu dia suka membaca buku."

Hasil wawancara dengan orang tua siswa HA yaitu Ibu IS, peneliti menyimpulkan bahwa terdapat faktor-faktor penyebab minat baca pada kelas $\mathrm{V}$ yang tinggi dalam pembelajaran daring di Desa Tendas yaitu salah satunya dari orang tua selalu menyediakan buku-buku dongeng untuk anak dan selalu memberikan dorongan semangat untuk anak walaupun di saat beliau sibuk bekerja. Peran orang tua dalam mendampingi dan memberikan dorongan kepada anak adalah hal penting, dalam masalah Ibu IS saat ini yaitu beliau sibuk bekerja tetapi masih bisa memberikan dorongan semangat kepada anak dan selalu menyediakan buku-buku dongeng untuk anaknya membaca. Sehingga anak bisa mendapatkan dorongan semangat dari perhatian orang tuanya.

Berdasarkan paparan di atas berdasarkan hasil wawancara dan hasil observasi peneliti dapat menyimpulkan bahwa faktor penyebab minat baca pada siswa kelas $\mathrm{V}$ yang tinggi dalam pembelajaran daring di Desa Tendas yaitu 
pengaruh dari faktor-faktor ligkungan, tersedianya sarana buku bacaan serta adanya dorongan dari lingkungan keluarga. Faizah (2021) menyebutkan jika orang tua memiliki peranan penting dalam membimbing dan mengawasi pelaksanaan pembelajaran anak selama masa pandemi. Dari hasil wawancara kepada informan anak, menyebutkan anak-anak merasa senang karena diberikan fasilitas buku oleh sekolah dan orang tua. Hal ini tampak dalam observasi yang peneliti lakukan.

\section{b. Cara Mempertahankan Minat Baca \\ Siswa Kelas V dalam Pembelajaran Daring di Desa Tendas}

Minat baca masing-masing individu selalu dikaitkan dengan kemauan atau dorongan yang menjembatani seseorang akan melaksanakan kemauannya. Berdasarkan dorongan tersebut akan menimbulkan kebiasaan yang berbeda sehingga minat baca akan muncul.

Cara untuk mempertahankan minat baca tersebut yakni adanya faktor pendukung. Mulyani (2018: 401) menyatakan bahwa faktor pendukung minat baca tersebut yaitu (1) adanya sarana, (2) adanya prasarana, (3) adanya dorongan dari lingkungan keluarga, (4) adanya dorongan dari luar keluarga.

Upaya orang tua dalam mempertahankan minat baca siswa yaitu dengan cara-cara memberi dorongan semangat dan motivasi terhadap anak agar anak terus mempertahankan minat membaca buku dan kegiatan belajarnya dalam pembelajaran daring saat ini. Menyediakan buku-buku bacaan agar anak tidak bosan di rumah dalam masa pandemi saat ini.

Masfuah (2016: 164) mengemukakan bahwa siswa sudah mempunyai pemikiran atau pendapat tetapi sulit untuk mengkomunikasikan. Siswa yang sering membaca buku akan pandai dan cepat tanggap dalam kemampuan berbahasanya dan ilmu pengetahuannya daripada siswa yang tidak pernah membaca atau malas membaca buku.

Rohani dan Ahmadi (dalam Mursalim, 2020:106), motivasi pada siswa dapat tumbuh melalui cara mengajar yang bervariasi, mengadakan pengulangan informasi, memberikan stimulus baru, misalnya melalui pertanyaan-pertanyaan kepada peserta didik, memberikan kesempatan kepada peserta didik menyalurkan belajarnya, menggunakan media dan alat bantu yang menarik perhatian peserta didik, seperti gambar, foto, video, dan lain sebagainya.

Roysa dan Hartani (2020: 320) mengemukakan bahwa menyikapi pelaksanaan pembelajaran secara daring, pihak sekolah telah melakukan koordinasi kepada siswa dan orang tua dalam mengambil kesepakatan terkait managemen waktu yang baik dalam pelaksanaan pembelajaran daring atau online menggunalan platform yang telah disediakan. Siswa dan orang tua sekarang sudah bisa mengakses media aplikasi secara berbayar dan gratis, siswa yang ingin membaca buku juga sekarang sudah bisa mengakses aplikasi bacaan buku di HP.

Banyak manfaat dan kesulitan dalam pembelajaran oline yang di lalui siswa dan orang tua. Roysa dan Hartani (2020: 320) mengemukakan bahwa kelebihan-kelebihan yang dimiliki dalam pelaksanaan penggunaan pembelajaran daring atau online, sangat bermanfaat dan mendukung dalam digunakannya pada sistem belajar mengajar pada situasi pandemi. Kesulitan dalam pembelajaran online yaitu mengarah ke sulit mendapatkan sinyal atau sulit memahami materi yang diberikan oleh guru.

Mursalim, dkk. (2020: 106) mengemukakan bahwa motivasi orang tua yang diberikan kepada anak sangatlah penting karena membawa pengaruh yang besar dalam keberhasilan anak tersebut di masa depan. Orang tua tidak hanya memberikan perhatian namun harus memberikan dorongan yang lebih dalam setiap tahap pembelajaran anak. Dalam perkembangannya seorang siswa tidak hanya butuh motivasi dan perhatian orang tua tapi juga dukungan secara nyata baik secara jasmani dan rohani sehingga pola belajarnya dapat menunjukan hasil.

Peneliti dapat menyimpulkan dari hasil wawancara beberapa orang tua siswa bahwa cara mempertahankan minat baca pada kelas $\mathrm{V}$ yang dalam pembelajaran daring di Desa Tendas yaitu dengan selalu menyediakan buku-buku bacaan untuk siswa agar siswa kelas $\mathrm{V}$ mendapatkan 
referensi buku yang banyak. Dorongan semangat dari keluarga atau orang tua dilakukan supaya anak dapat semangat dan gemar membaca buku. Menyediakan waktu untuk siswa dalam membaca buku agar siswa lebih sering membaca dan supaya siswa mendapatkan ilmu pengetahuan dan wawasan akan manfaat dari membaca buku. Sekolah dan orang tua berkolaborasi untuk menjaga minat baca anak. Pihak sekolah selalu memantau kegiatan anak selama pembelajaran daring dari rumah masingmasing melalui pantauan orang tua. Selain itu, membentuk jejaring pertemanan yang memiliki minat baca yang baik juga menjadi salah satu upaya untuk tetap mempertahankan minat baca anak selama pembelajaran daring berlangsung. Ditemukan beberapa kali informan membaca buku cerita bersama-sama di salah satu rumah informan.

\section{SIMPULAN}

Berdasarkan hasil penelitian di atas, dapat disimpulkan. Tingginya minat baca pada siswa kelas V SD di Desa Tendas disebabkan beberapa faktor penyebab yaitu pengaruh dari faktorfaktor ligkungan, tersedianya sarana buku bacaan serta adanya dorongan dari lingkungan keluarga. Sementara cara mempertahankan minat baca siswa yaitu dengan penambahan sarana dan prasarana berupa buku bacaan yang lebih bervariasi, kerjasama antara pihak sekolah dan orang tua untuk memberikan kesempatan pada siswa untuk membaca buku yang disukainya, dan membangun jaringan teman bermain yang memiliki minat baca yang baik.

\section{DAFTAR PUSTAKA}

Ama, Roy Gustaf Tupen. 2021. Minat Baca Siswa Ditijau Dari Persepsi Keterlibatan Orangtua Dalam Pendidikan. Edunesia: Jurnal Ilmiah Pendidikan. 2 (1): 23-28.

Apriliani, Siwi Pawestri dan Elvira Hoesein Radia. 2020. Pengembangan Media Pembelajaran Buku Cerita Bergambar untuk Meningkatkan Minat Membaca Siswa Sekolah Dasar. Jurnal Basicedu, 4 (4): $994-1003$.

Artana, I Ketut. 2017. Anak, Minat Baca, dan Mendongeng. Arcaya Pustaka, 3 (1): 3544.
Faizah, Nur Reza, dkk. 2021. Sikap Sopan Santun Anak Dilihat dari Pola Asuh Orang Tua Tunggal. Jurnal Prasasti Ilmu, 1 (1): $13-18$

Masfuah, Siti. 2018. Learning Student Teams Achievement Division (STAD) Untuk Meningkatkan Kemampuan Komunikasi Siswa Sekolah Dasar. Jurnal TELECON. Kudus: Badan Penerbit Universitas Muria Kudus.

Moleong, Lexy J..2012. Metodologi Penelitian Kualitatif. Bandung: PT. Remaja Rosdakarya.

Mulyani, Emi Tri. 2018. Analisis Faktor-faktor Pendukung Minat Baca Mahasiswa Jurusan Tari di Perpustakaan Isi Surakarta. Libraria, 6 (2): 45-58.

Mursalim, Solehun, Rian Pramudia. 2020. Pengaruh Motivasi Orang Tua terhadap Minat Baca Siswa Kelas III SD Inpres 26 Kabupaten Sorong Tahun Pelajaran 2016/2017. Jurnal Papeda, 2 (2): 33-48.

Patiung, Dahlia. 2016. Membaca Sebagai Sumber Pengembangan Intelektual. AlDaulah, 5 (2): 43-50.

Putra, Prisma Adi, dkk. 2021. Penerapan Model Pembelajaran Teams Game Tournament Berbantu Media Pemprof untuk Meningkatkan Hasil Belajar Siswa Kelas IV Sekolah Dasar. Jurnal Prasasti Ilmu, 1(1): 1-12.

Roysa, Mila dan Anisa Hartani. 2020. Aplikasi Daring Quizziz Sebagai Solusi Pembelajaran Menyenangkan di Masa Pandemi. LENTERA: Jurnal Ilmiah Kependidikan. 13 (2): 315-326.

Sugiyono. 2016. Metode Penelitian Pendidikan. Bandung: Alfabeta.

Tarigan, Henry Guntur. 2008. Membaca Sebagai Suatu Ketrampilan Berbahasa. Bandung: Angkasa Bandung. 